\title{
不同施氮水平下甘蓝型油菜发育种子中基因表达谱差异分析
}

间贵欣陈碧云许锟高桂珍吕培军伍晓明*李锋李俊

中国农业科学院油料作物研究所 / 农业部油料作物生物学与遗传育种重点实验室, 湖北武汉 430062

摘 要: 氮肥是油菜生长发育需要的重要营养元素之一, 增施氮肥可提高油菜籽产量和蛋白质含量, 但降低种子含 油量。篮选氮肥不敏感油菜基因型、发掘氮肥响应基因及调控网络研究尚不多见。本研究以油菜中双 11 和德国品种 Parter 为材料, 设置 4 个氮水平(施用尿素 $0 、 90 、 180$ 和 $270 \mathrm{~kg} \mathrm{hm}^{-2}$ ), 随机区组试验, 利用 Agilent 油菜基因芯片在 全基因组水平分析施氮 $\left(180 \mathrm{~kg} \mathrm{hm}^{-2}\right.$ )和未施氮(对照)处理授粉 $25 \mathrm{~d}$ 种子的基因表达谱。结果显示，随着施氮量的增加， 种子含油量降低, 而蛋白质含量增加, 且在 2 个品种中的变化程度不同, Parter 含油量的下降水平比中双 11 显著。处 理与对照相比, 中双 11 和 Parter 分别有 827 个和 3676 个差异表达基因, 明显存在基因型的差异; 2 个品种中共同的 差异表达基因有 278 个，其中上调表达的 151 个，下调表达的 80 个，差异表达在 10 倍以上的基因有 4 个。根据基因 功能注释, 2 个品种中的差异表达基因分子功能主要为催化、结合和转录调节活性, 参与细胞、代谢和应激等生物过 程, 约 50\%的差异基因未得到功能注释。选择 8 个差异表达基因进行实时苂光定量 PCR 分析, 结果显示 2 种方法的 检测结果吻合率为 $94 \%$, 表明检测结果具有一定的生物重复性。本结果为进一步篮选油菜氮肥敏感基因型、开展氮 应答机制研究提供了有用信息。

关键词：基因芯片；氮肥；含油量和蛋白含量；差异表达基因；实时苂光定量 PCR

\section{Differential Gene Expression Profiles in Developing Seeds of Brassica napus L. under Different Nitrogen Application Levels}

\author{
YAN Gui-Xin, CHEN Bi-Yun, XU Kun, GAO Gui-Zhen, LÜ Pei-Jun, WU Xiao-Ming ${ }^{*}$, LI Feng, and LI Jun
}

Oil Crops Research Institute, Chinese Academy of Agricultural Sciences / Key Laboratory of Biology and Genetic Improvement of Oil Crops, Ministry of Agriculture, Wuhan 430062, China

\begin{abstract}
Nitrogen is one of the major fertilizers to Brassica napus L., it has concluded that increasing nitrogen application would raise seed yield, enhance protein abundance but decrease oil content. Up-to-date, little is known on screening nitrogen-tolerant $B$. napus and identifying nitrogen-response genes and their networks. In the paper, we designed four nitrogen application levels $\left(0,90,180\right.$, and $\left.270 \mathrm{~kg} \mathrm{ha}^{-1}\right)$ using Brassica napus accessions Zhongshuang 11 and Parter (from Germany) with randomized block design. The results indicated that the seed protein content increased whereas oil content decreased with increasing nitrogen levels. There existed variance in protein and oil contents between Zhongshuang 11 and Parter. The oil content decline was obviously higher in Parter than in Zhongshuang 11. The comparison of 25 days after pollination (DAP) seeds by Agilent oilseed microarrays at the whole-genome level between $180 \mathrm{~kg} \mathrm{ha}^{-1}$ nitrogen fertilizer treatment and CK showed that Zhongshuang 11 contained 827 differential expressed genes, Parter comprised 3676 differentially expressed genes, and two varieties jointly shared 278 differentially expressed genes, including 151 genes up-regulated and 80 genes down-regulated, and four genes with at least 10 -fold difference expression. The functional classification of differentially expressed genes indicated that they mainly had binding, catalytic activities and transcriptional regulation activities. Most of them were involved in cellular, metabolic, and stimulative processes. The genes (about 50\%) without function annotation should be studied further. Additionally, the expression of eight differentially expressed genes was validated by Quantitative RT-PCR. The results from the two methods were $94 \%$ consistent, which indicated that the microarray results were biologically reproducible. Our results shade light on exploring mechanism of nitrogen response and nitrogen-tolerance genotype identification in B. napus.
\end{abstract}

Keywords: Microarray; Nitrogen fertilizer; Oil and protein content; Differentially expressed genes; Quantitative RT-PCR

本研究由国家自然科学基金青年项目(31100911),湖北省自然科学基金项目(2011CDB353)和国家重点基础研究发展计划(973计划)项 目(2011CB109300)资助。

*通讯作者(Corresponding author): 伍晓明, E-mail: wuxm@oilcrops.cn, Tel: 027-86812906

第一作者联系方式: E-mail: ygx_928@126.com

Received(收稿日期): 2012-03-16; Accepted(接受日期): 2012-06-10; Published online(网络出版日期): 2012-09-10.

URL: http://www.cnki.net/kcms/detail/11.1809.S.20120910.1324.005.html 
油菜是世界第二大油料作物, 也是中国重要的 油料作物, 菜籽油占国产食用植物油的近 $57 \%^{[1]}$, 菜籽油生产对保障食用油安全至关重要。由于油脂 是油菜生产的最终目标产物, 产油量较种子产量更 能反映实际生产成效。决定油菜产油量高低的 2 个 最重要构成因子是种子含油量和单位面积种子产量, 这 2 个因子的变化直接影响产油量。

氮肥是保障油菜生长发育的最重要营养元素 ${ }^{[2]}$ 。 研究结果表明, 增施氮肥能显著提升种子产量, 但 同时又会降低种子含油量并增加菜籽粗蛋白含量 ${ }^{[3-5]}$, 因此, 增施氮肥尽管能显著提升种子产量, 但不一 定能相应地提升产油量。施氮后, 菜籽含油量降低, 而籽粒蛋白质含量增加 ${ }^{[6-7]}$, 可能是种子内油脂和蛋 白质合成过程中对碳源的竞争造成了两者之间的负 相关 ${ }^{[8-9]}$ 。油脂和蛋白质的合成是一个极其复杂的生 物合成过程, 涉及上百个基因及其编码的酶类 ${ }^{[10]}$, 推测施氮后与油脂合成与转运相关基因可能受到抑 制, 而与蛋白质合成与转运相关基因受到诱导, 从 而导致含油量下降，而蛋白质含量上升。考虑到油 菜品种资源的遗传多样性, 有必要确定是否存在施 氮后含油量下降不显著的品种, 如果存在这样的品 种资源, 今后就能培育出施氮后, 产油量显著提升 的高产高油品种, 同时通过对其油脂和蛋白质的合 成基因网络研究，明确控制碳源分流的关键基因或 基因网络，指导油菜分子育种。

基因表达谱芯片(gene expression profiling)是目 前高通量研究基因表达的有效手段 ${ }^{[11]}$, 它可以同时 分析多组不同来源 mRNA 的差异, 快速获得大量基 因在 mRNA 水平上的表达信息。通过比较分析基因 表达谱的差异, 可以从全基因组表达水平研究基因 之间的网络关系, 并发现重要功能基因 ${ }^{[12-16]}$ 。本文 的研究目的在于利用基因芯片技术分析施氮和未施 氮条件下油菜发育种子中基因表达谱的差异, 寻找 对氮肥响应的基因或基因网络, 揭示氮肥对油菜种 子中蛋白质和油脂合成的调控机制。

\section{1 材料与方法}

\section{1 试验设计}

试验于中国农业科学院油料作物研究所试验地 进行, 未施肥的耕层土壤 $(0 \sim 20 \mathrm{~cm})$ 每千克土碱解氮 含量为 $184.3 \mathrm{mg}$, 试验中磷肥为过磷酸钙 (含 $\mathrm{P}_{2} \mathrm{O}_{5}$ $16 \%$ ), 钾肥为氯化钾(含 $\mathrm{K}_{2} \mathrm{O} 60 \%$ ), 各处理均基施 磷肥 $90 \mathrm{~kg} \mathrm{hm}^{-2}$, 钾肥 $180 \mathrm{~kg} \mathrm{hm}^{-2}$; 氮肥为尿素(含
$\mathrm{N} 46 \%$ ), 施于苗期, 试验设 4 个氮肥梯度, 分别为 0(A)、90(B)、180(C)和 $270 \mathrm{~kg} \mathrm{hm}^{-2}$ (D), 每个处理(小 区)面积 $4.8 \mathrm{~m}^{2}$, 种植密度每平方米 15 株, 各处理重 复 3 次, 随机区组排列。

\section{2 植物材料}

选用甘蓝型油菜(Brassica napus L.) 德国品种 Parter 和中国品种中双 11 , 盛花期每个小区选取 10 个单株，自交授粉前一天，将主花序上已经开过的 花和已结的荚果去掉后套袋, 令第 2 天对主花序上 开放的 4 5 朵花自花授粉, 并作标记, 授粉当天记 为第 0 天(day after pollination, DAP), $5 \mathrm{~d}$ 后去袋子。 取开花后 25DAP 的种子, 将每次取材随机分成 3 份, 作为 3 次重复, 于液氮中速冻后保存在 $-70^{\circ} \mathrm{C}$ 冰箱, 以保证 RNA 长度的完整, 备作 RNA 提取。

将收获的自交种子自然晾干，采用 Foss NIRSystems 5000 近红外分析仪分析测定自交油菜籽的 含油量和蛋白质含量。

\section{3 种子 RNA 的提取}

取 $100 \mathrm{mg}$ 种子于碾钵, 加液氮碾磨, 用 $1.5 \mathrm{~mL}$ 预冷的提取 buffer ( $8 \mathrm{~mol} \mathrm{~L}^{-1} \mathrm{LiCl}, 2 \% \beta$-巯基乙醇) 悬浮粉末并混匀, $4^{\circ} \mathrm{C}$ 过夜后离心 $4 \mathrm{~s}$, 取上清并于 $16000 \times g, 4^{\circ} \mathrm{C}$ 离心 $30 \mathrm{~min}$, 弃上清液, $70 \%$ 乙醇洗沉 淀，短暂风干。用 $1 \mathrm{~mL}$ 溶解缓冲液 $(0.5 \% \mathrm{SDS}, 100$ mmol L ${ }^{-1} \mathrm{NaCl}, 25 \mathrm{mmol} \mathrm{L}{ }^{-1}$ EDTA, $10 \mathrm{mmol} \mathrm{L}^{-1}$ Tris- $\mathrm{HCl}, \mathrm{pH} 7.6,2 \% \beta$-㧧基乙醇)溶解沉淀。用 $\mathrm{pH}$ 4.6 的水饱和酚抽提 1 次, 酚: 氯仿: 异戊醇 $=25: 24: 1$ 和氯仿：异戊醇 $=24: 1$ 各抽提 1 次, 每 次抽提均以 $16000 \times \mathrm{g}, 4^{\circ} \mathrm{C}$ 离心 $15 \mathrm{~min}$ 。抽提完再用 0.1 倍体积的 $3 \mathrm{mmol} \mathrm{L}^{-1}$ 醋酸钠和 1.5 倍体积的无水 乙醇沉淀 RNA $\left(-20^{\circ} \mathrm{C}, 15 \mathrm{~min}\right)$, 然后 $16000 \times \mathrm{g}, 4^{\circ} \mathrm{C}$ 离心 $15 \mathrm{~min}$ ，弃上清液，用 $70 \%$ 乙醇洗沉淀，最后将 RNA 溶解在 DEPC 处理过的水中 ${ }^{[17-18]}$ 。

取 $2 \mu \mathrm{L}$ RNA 作 BECKMAN DU650核酸/蛋白质 分析仪检测, 得到 RNA 的浓度和 $\mathrm{OD}_{260} / \mathrm{OD}_{280}$ 比值 ( $\mathrm{OD}_{260 / 280} \approx 1.8$ 的 RNA 质量符合要求); 用 $1.0 \%$ 琼脂 糖凝胶电泳检测总 RNA 的 $28 \mathrm{~S}$ 和 $18 \mathrm{~S}$ rRNA 比例, 以评估总 RNA 的完整性。

\section{4 基因芯片实验与数据分析}

25DAP 是油菜种子油脂和蛋白合成的关键时 期 ${ }^{[17]}$, 选择该时期 2 个品种处理(施尿素 $180 \mathrm{~kg} \mathrm{hm}^{-2}$ ) 和对照(未施氮肥)的材料做基因芯片分析。

采用 Agilent 油菜 $4 \times 44 \mathrm{k}$ DNA 芯片（由上海伯豪 生物技术有限公司-生物芯片上海国家工程研究中 
心提供)，共含 20332 个基因。芯片实验的整个过程, 包括总 RNA 纯化质检和定量(LAB-ON-A-CHIP 系 统)、cDNA 探针制备、芯片杂交、洗涤、扫描、图 像分析和数据处理, 均在上海伯豪生物技术有限公 司进行。

比较分析 2 张芯片的杂交数据, 以 2 个品种对 照组为参照, 处理中种子基因表达变化的 Signal $\log _{2}$ Ratio 值确定基因的上下调关系，挑选 Fold Change 大于等于 2 的基因为差异基因。

\section{5 差异表达基因的功能预测}

利用 COG 库(cluster of genes)和 COGNITOR 程 序(http://www.ncbi.nlm.nih.gov/COG/), 预测差异表 达基因的功能。

\section{6 实时苂光定量 PCR (Quantitative RT-PCR)} 验证基因芯片结果

使用 TOYOBO 公司的 ReverTra Ace- $\alpha$ 试剂盒合 成第一链 cDNA，反应体系中含 $1 \times$ ReverTra buffer、 $2 \mu \mathrm{L}$ dNTPs、1 U RNase 抑制剂、1 U ReverTra Ace 反转录酶、 $2 \mu \mathrm{L}$ 总 RNA, 用 DEPC 处理过的水补充 体积至 $20 \mu \mathrm{L}$ 。反应程序为 $30^{\circ} \mathrm{C} 5 \mathrm{~min}, 42^{\circ} \mathrm{C} 30 \mathrm{~min}$, $99^{\circ} \mathrm{C} 5 \mathrm{~min}$ 。将得到的 cDNA 稀释 10 倍后分装, 用 于 PCR 扩增。

在已注释的差异表达基因中, 挑选差异表达程 度不同的 8 个基因, 以油菜 $\beta$-actin 基因为内参对照,
使用 TOYOBO 公司的 $2 \times$ Real-time PCR Master Mix, 进行实时苂光定量 PCR 的检测, 以验证基因芯片的 分析结果。苂光定量 PCR 的反应体系 $20 \mu \mathrm{L}$, 含 10 $\mu \mathrm{L} 2 \times$ Real-time PCR Master Mix、 $400 \mathrm{nmol} \mathrm{L}^{-1}$ 正向

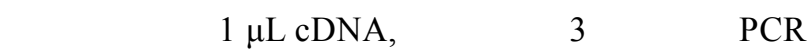
扩增反应程序为: $94^{\circ} \mathrm{C}$ 预变性 $2 \mathrm{~min}$; 随后进行 40 个 循环, 包括 $94^{\circ} \mathrm{C}$ 变性 $20 \mathrm{~s}, 56^{\circ} \mathrm{C}$ 退火 $30 \mathrm{~s}$; 随后 55 $95^{\circ} \mathrm{C}$ 熔解曲线, 每 $0.5^{\circ} \mathrm{C}$ 读板 1 次, 来检测扩增产物 的特异性; 最后 $16^{\circ} \mathrm{C}$ 保存。对每个基因, 进行 3 次 平行实验。委托上海生工公司合成定量 PCR 引物(表 $1)$, 使用 Bio-Rad iQ5 苂光定量 PCR 仪及 $2^{-\Delta \Delta \mathrm{Ct}}$ 法分 析数据 ${ }^{[19]}$ 。

\section{2 结果与分析}

\section{1 不同氮肥条件下的种子含油量与蛋白质含量} 随着施氮量的增加，2 个品种种子含油量均降低， 而蛋白质含量均提高。方差分析表明，不同施氮量 下含油量和蛋白含量差异均达极显著水平 $(P<0.001)$ (表 2)。由表 2 所示，中双 11 在不同的施氮水平下，B、 $\mathrm{C}$ 与 $\mathrm{A}$ 处理的含油量无显著差异, 但 $\mathrm{D}$ 与 $\mathrm{A}$ 处理间 含油量差异极显著; C、D (两者之间无显著差异)与 A 处理的蛋白含量差异达极显著水平。Parter 在不同的 施氮水平下, $\mathrm{C} 、 \mathrm{D}$ (两者之间无显著差异)与 $\mathrm{A} 、 \mathrm{~B}$ 处理(两者之间无显著差异)的含油量差异达极显著

表 1 本研究中所用到的引物及其扩增产物

Table 1 List of primer sequences and amplicon sizes

\begin{tabular}{|c|c|c|c|c|}
\hline $\begin{array}{l}\text { 基因名 } \\
\text { Gene name }\end{array}$ & $\begin{array}{l}\text { 基因详细名称 } \\
\text { Gene annotation }\end{array}$ & $\begin{array}{c}\text { 引物序列 } \\
\text { Primer sequence }\left(5^{\prime}-3^{\prime}\right)\end{array}$ & $\begin{array}{c}\text { PCR 产物长度 } \\
\text { Amplicon size } \\
\text { (bp) }\end{array}$ & $\begin{array}{c}\text { 登录号 } \\
\text { Accession } \\
\text { number } \\
\end{array}$ \\
\hline Up1 & Unknown & F: GTGTTTGAGGCATCCCGAGT & 113 & CD819016 \\
\hline \multirow[t]{3}{*}{ Up2 } & & R: TCCAAGGTCGAAATAACGCC & & \\
\hline & Unknown & F: TTCACGTCAGGAGAAGTTAGGT & 118 & EV172367 \\
\hline & & R: CAGGTACATGCATGAGGGTATT & & \\
\hline \multirow[t]{2}{*}{$D 1$} & Unknown & F: TCCACAAAGACATCAAAGCTG & 114 & CD826382 \\
\hline & & R: GTCTTCCCTTCTTGATATTGTCC & & \\
\hline \multirow[t]{2}{*}{ DGAT2 } & Acyl-CoA: diacylglycerol acyltransferase & F: CATGACCTGATGAACCGCAAAG & $111^{[17]}$ & AF155224 \\
\hline & & R: ACGGCTACCAAAAGGATACAAAA & & \\
\hline \multirow[t]{2}{*}{$P E P C$} & Phosphoenolpyruvate carboxylase & F: GGTTGGGTTTATTGGTTTGTTTATG & $134^{[17]}$ & AJ223497 \\
\hline & & R: ATTCCCTTGCTCGGTTTTGTTA & & \\
\hline \multirow[t]{2}{*}{ FAE1 } & Fatty acid elongase 1 & F: GTCAGGCTTTAAGTGTAACAGTGCA & $159^{[17]}$ & AF009563 \\
\hline & & R: TTATTAGGACCGACCGTTTTGG & & \\
\hline \multirow[t]{2}{*}{ ACCase } & Homomeric acetyl CoA carboxylas & F: AGGACTTGCCAATCTTCTAAAC & $157^{[17]}$ & X77382 \\
\hline & & R: AGCTTCTTTCACCGTAGGACAC & & \\
\hline \multirow[t]{2}{*}{$\beta$-actin } & Housekeep genes & F: CTGGAATTGCTGACCGTATGAG & $145^{[17]}$ & AF111812 \\
\hline & & R: ATCTGTTGGAAAGTGCTGAGGG & & \\
\hline
\end{tabular}

$\mathrm{F}$ ：正向引物; R: 反向引物。 $\mathrm{F}$ : forward primer; R: reverse primer. 
表 2 氮肥对油菜含油量和蛋白质含量的影响

Table 2 Effect of nitrogen on seed oil and protein contents of rapeseed (\%)

\begin{tabular}{cccccc}
\hline 氮肥处理 & \multicolumn{2}{c}{ 中双 11 Zhongshuang 11} & & \multicolumn{2}{c}{ Parter } \\
\cline { 2 - 3 } \cline { 5 - 6 } $\begin{array}{c}\text { Treatment } \\
\left(\mathrm{kg} \mathrm{hm}^{-2}\right)\end{array}$ & $\begin{array}{c}\text { 含油量 } \\
\text { Oil content }\end{array}$ & $\begin{array}{c}\text { 蛋白含量 } \\
\text { Seed protein }\end{array}$ & & $\begin{array}{c}\text { 含油量 } \\
\text { Oil content }\end{array}$ & $\begin{array}{c}\text { 蛋白含量 } \\
\text { Seed protein }\end{array}$ \\
\hline $0(\mathrm{~A}$, control $)$ & $45.89 \mathrm{aA}$ & $21.65 \mathrm{bC}$ & & $43.45 \mathrm{aA}$ & $20.88 \mathrm{cC}$ \\
$90(\mathrm{~B})$ & $45.19 \mathrm{abAB}$ & $22.98 \mathrm{bBC}$ & & $42.48 \mathrm{aA}$ & $22.51 \mathrm{bB}$ \\
$180(\mathrm{C})$ & $43.85 \mathrm{bcAB}$ & $25.23 \mathrm{aAB}$ & & $38.92 \mathrm{bB}$ & $26.02 \mathrm{aA}$ \\
$270(\mathrm{D})$ & $43.18 \mathrm{cB}$ & $26.97 \mathrm{aA}$ & & $38.82 \mathrm{bB}$ & $26.73 \mathrm{aA}$ \\
\hline
\end{tabular}

小写字母代表 0.05 显著水平, 大写字母代表 0.01 显著水平。

Values within a column followed by different letters are significantly different at 0.05 probability level (small letter) and at 0.01 probability level (capital letter).

水平。 $\mathrm{B} 、 \mathrm{C} 、 \mathrm{D}$ 与 $\mathrm{A}$ 处理蛋白含量达极显著水平。

选择处理 $\mathrm{A}$ 和处理 $\mathrm{C}$ 的材料作基因芯片的分 析。处理 $\mathrm{C}$ 跟处理 $\mathrm{A}$ 比较, 中双 11 的含油量显著差 异, Parter 的含油量差异达极显著水平, 2 个品种的蛋 白含量均达极显著差异, 因此, 通过基因芯片分析 可以获得不同表型的差异表达基因。

\section{2 油菜总 RNA 的质量评估}

经琼脂糖凝胶电泳检测, 所提取的 RNA 的完整 性较好(图 1), 通过核酸/蛋白质分析仪粗测 RNA 的 浓度, 各送样 $10 \mu \mathrm{g}$ 到公司, 经公司质控评估, RNA 样品符合作基因芯片的要求。

\section{3 不同氮水平下油菜种子中的基因差异表达} 分析

Agilent 表达谱芯片用重复探针点(10 次重复)信 号的 $C V$ 值来计算芯片的稳定性, 其质控标准是 $C V$ 值小于 $15 \%$ 。本次 4 张基因芯片结果的 $C V$ 值均在 $5 \% \sim 7 \%$ 之间，基因的检出率在 $81 \% \sim 84 \%$ 之间，说明
分析结果是合格可用的。

比较分析施氮肥跟未施氮肥的基因芯片数据 (图 2), 中双 11 的差异表达基因有 827 个, 表达上调 的基因 481 个, 表达下调的基因 346 个。其中差异 表达倍数在 2.0 3.0 之间的有 524 个, 占差异基因总 数的 $64 \%, 3.0 \sim 5.0$ 倍的差异基因有 189 个, 占总数的 $23 \%$, 差异表达倍数大于 20 的基因有 12 个。而 Parter 差异表达的转录本 3676 条, 其中表达上调的 1830 条, 表达下调的 1846 条, 差异表达倍数在 2.0 3.0 范 围的基因有 2026 个，占差异基因总数的 55\%, 3.0 5.0 之间的差异基因有 892 个，占总数的 $24 \%$, 差异表 达倍数大于 50 的基因有 54 个。

比较发现 Parter 中的差异基因数远远高于中双 11；2 个品种中约 $80 \%$ 差异基因的差异倍数分布在 2.0 5.0 之间, 随着差异倍数的增大差异基因数目相 应降低; 2 个品种中共同的差异表达基因比较少，仅 有 278 个, 其中共同上调的 151 个, 下调的 80 个。

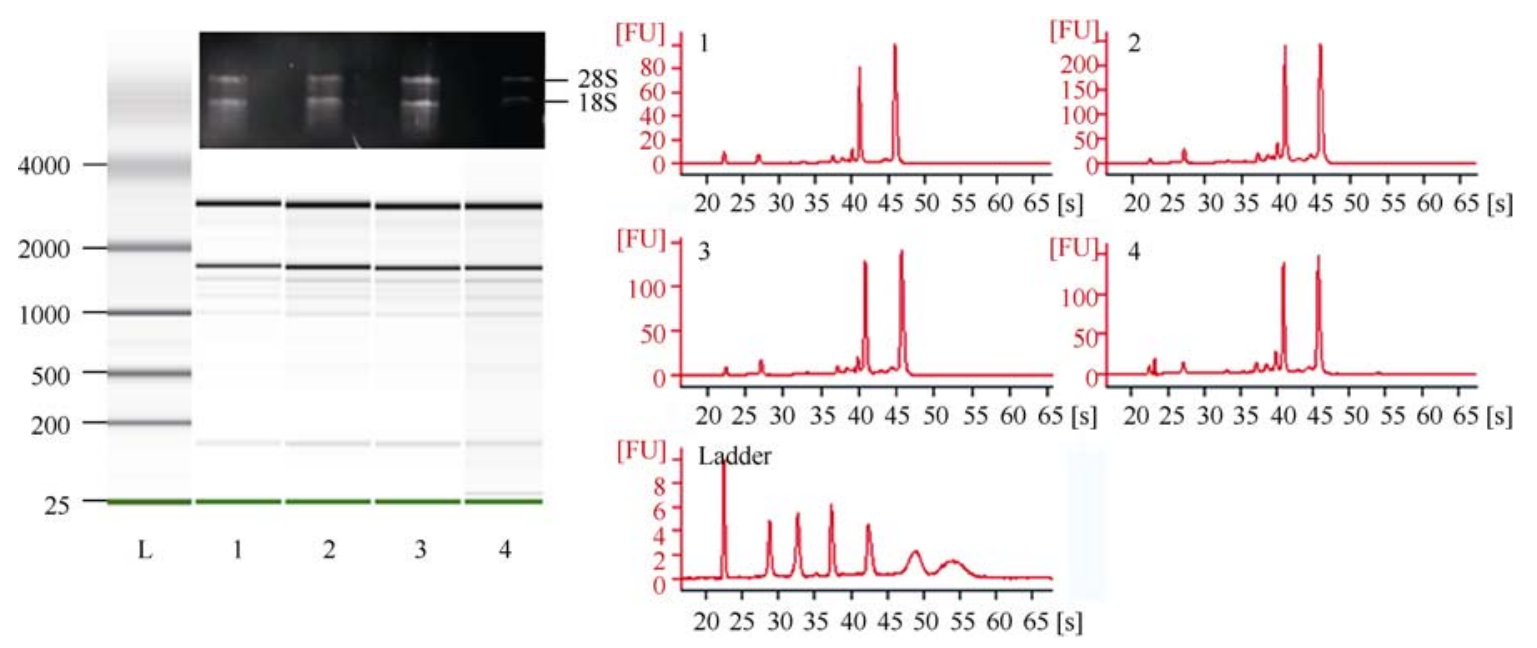

图 1 中双 11 和 Parter 种子总 RNA 的电泳图

Fig. 1 Electrophoretic gel image of the total RNA from seeds of Zhongshuang 11 and Parter

1: 中双 11 (对照); 2: 中双 11 (处理); 3: Parter (对照); 4: Parter (处理); L: ladder。

1: Zhongshuang 11 (control): 2: Zhongshuang 11 (treatment); 3: Parter (control); 4: Parter (treatment); L: ladder. 


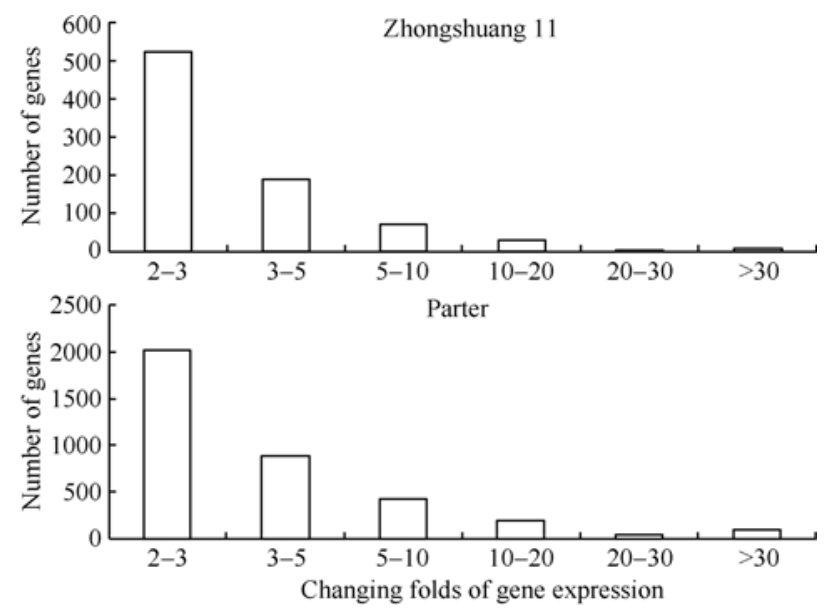

图 2 中双 11 与 Parter 具不同倍数的差异表达基因的分布 Fig. 2 Distribution of differentially expressed genes with different folds of expression levels in Zhongshuang 11 and Parter

相对于整体的差异表达基因，表达趋势一致的基因 在数量上较少, 而且 2 个品种基因表达的上调或下调 显著程度存在差异。

\section{4 差异表达基因的功能预测}

在对基因芯片所有基因整体分析基础上，采用 $\mathrm{GO}$ 注释系统对差异表达倍数在 2 倍或 2 倍以上基因 进行功能注释。表 3 表明, 以分子功能分类, 注释了 379 个差异基因, $92 \%$ 的差异基因具有催化活性 (catalytic activity)、结合(binding)和转录调节活性 (transcription regulation activity), 其他基因分别具有 转运蛋白活性(transporter activity)、电子载体活动 (electron carrier activity)和酶调 (enzyme regulator activity)等活性。以基因参与的生物过程分类, 中双 11 中注释了 676 个差异基因, 70\%的差异基因被分在 代谢过程 (metabolic process)、细胞过程 (cellular process)、应激过程(response to stimulus)和生物调节 (biological regulation)过程, 其他基因分别参与了生 物过程的调控(regulation of biological process)、多个 生物过程(multi-organism process)、多细胞生物过程 (multicellular organismal process)、定位(localization)、 发育过程(developmental process)、生殖(reproduction)、解剖构造的形成(anatomical structure formation) 和免疫系统(immune system process)等生物过程。以 细胞组分分类, 中双 11 中有 474 个差异基因得到注 释, 94\%的差异基因被归于 2 类, 细胞 (cell)和细胞器 (organelle), 其他基因参与大分子复合体 (macromolecular complex)、胞外区域(extracellular region)和包 膜(envelope)等的形成。

由表 3 可知, 以分子功能分类, Parter 中有 1240
个差异基因得到注释, $85 \%$ 的差异基因具有催化、结 合和转录调节活性。以基因参与的生物过程分类, Parter 中有 2229 个差异基因得到注释, 65\%的差异基 因参与细胞、代谢、应激和生物调节 4 个过程。以细 胞组分分类, Parter 中有 1334 个差异基因得到注释, $89 \%$ 的差异基因被归于 2 类, 细胞(cell)和细胞器 (organelle), 11\%的基因定位在高分子复合体、胞外区 域、细胞外壁等部位。

比较发现, 2 组差异基因在不同功能分类中的主 要功能是吻合的, 主要具有催化活性、结合和转录 调节活性等分子功能, 参与细胞、代谢、应激和生 物调节 4 个生物过程, 参与细胞和细胞器的形成。同 时我们分析了中双 11 和 Parter 两组差异基因中共同 的差异基因, 发现 2 个品种共同的差异基因和 2 个品 种差异表达的基因在不同功能分类中的主要功能也 是吻合的(表 3 )。

$\mathrm{GO}$ 分类可以从整体水平分析基因表达差异，阐 明施氮肥导致不同品种种子发育过程中产生差异的 主要功能类别。但是, 为了更明确地了解在氮肥诱 导下差异基因的具体功能，我们逐一分析了 2 个品种 共同的差异表达基因。结果发现约 50\%的基因功能 未知, 它们在油菜油脂和蛋白的形成过程中的作用 以及对氮肥的应答功能还需进一步研究。表 4 中列 出了 2 个品种中部分共同的差异表达基因, 主要是一 些与碳代谢相关的酶类和信号调控相关的基因。如 碳代谢 (carbon metabolism) 相关基因，包括葡萄糖 -6 - 磷酸转运体、 $\beta$-葡萄糖苷酶、 $\alpha / \beta$ 水解酶家族、 6 磷酸果糖激酶、蛋白激酶、糖基水解酶等, 信号及 调控(signal and regulator)相关基因, 包括乙烯应答 转录因子、乙烯应答元件结合因子、钙依赖性蛋白 激酶、㕫哚乙酸氨基化合成酶、可变剪接调控蛋白、 丝裂原活化蛋白激酶等; 转录(transcription)相关基 因, 包括锌指蛋白家族、WRKY DNA 结合蛋白, myb 家族转录因子、病程相关蛋白、抗病蛋白 (disease resistance protein RPM1)、富含亮氨酸重复序列的蛋 白、TRAF-like 家族蛋白等。

为了更明确地了解 2 个品种共同差异显著基因 的具体功能, 我们逐一分析 2 个品种中共同上调或 下调在 10 倍以上的基因, 其中上调的基因只有 3 个, 其功能都为假定的, 一个为假定的镁离子鳌合酶 (putative magnesium-chelatase subunit chlI), 与膜及 运输(membrane and transport)有关系; 一个为假定的 水溶性叶绿素结合蛋白 (water-soluble chlorophyllbinding protein, WSCP); 另外 1 个是假定未知功能 
表 3 差异表达基因的 GO 功能分类

Table 3 Statistics of differentially expressed genes assigned to GO functional categories

\begin{tabular}{|c|c|c|c|c|c|c|}
\hline \multirow{2}{*}{$\begin{array}{l}\text { 本体与基因本体术语 } \\
\text { Ontology and GO term }\end{array}$} & \multicolumn{2}{|c|}{ 中双 11 Zhongshuang 11} & \multicolumn{2}{|c|}{ Parter } & \multicolumn{2}{|c|}{ 共有 Share } \\
\hline & $\begin{array}{l}\text { 数目 } \\
\text { No. }\end{array}$ & $\begin{array}{c}\text { 百分比 } \\
\text { Percentage (\%) }\end{array}$ & $\begin{array}{l}\text { 数目 } \\
\text { No. }\end{array}$ & $\begin{array}{c}\text { 百分比 } \\
\text { Percentage (\%) }\end{array}$ & $\begin{array}{l}\text { 数目 } \\
\text { No. }\end{array}$ & $\begin{array}{c}\text { 百分比 } \\
\text { Percentage (\%) }\end{array}$ \\
\hline 分子功能 Molecular function & 379 & 100 & 1240 & 100 & 107 & 100 \\
\hline 催化活性 Catalytic activity & 179 & 48 & 522 & 42 & 50 & 47 \\
\hline 结合 Binding & 142 & 38 & 440 & 35 & 39 & 36 \\
\hline 转录调节活性 Transcription regulator activity & 24 & 6 & 102 & 8 & 7 & 7 \\
\hline 转运活性 Transporter activity & 15 & 4 & 79 & 6 & 5 & 5 \\
\hline 电子载体活性 Electron carrier activity & 7 & 2 & 39 & 3 & 0 & 0 \\
\hline 酶调活性 Enzyme regulator activity & 6 & 2 & 24 & 2 & 6 & 6 \\
\hline 分子传感器活性 Molecular transducer activity & 1 & 0 & 15 & 1 & 0 & 0 \\
\hline 营养库活性 Nutrient reservoir activity & 2 & 0 & 7 & 1 & 0 & 0 \\
\hline 结构分子活性 Structural molecular activity & 2 & 0 & 6 & 0 & 0 & 0 \\
\hline 抗氧化活性 Antioxidant activity & 1 & 0 & 6 & 0 & 0 & 0 \\
\hline 生物学过程 Biological process & 676 & 100 & 2229 & 100 & 189 & 100 \\
\hline 细胞过程 Cellular process & 155 & 23 & 498 & 22 & 40 & 21 \\
\hline 代谢过程 Metabolic process & 156 & 23 & 465 & 21 & 41 & 22 \\
\hline 应激反应 Response to stimulus & 72 & 11 & 246 & 11 & 30 & 16 \\
\hline 生物调节 Biological regulation & 52 & 8 & 199 & 9 & 14 & 7 \\
\hline 生物过程调节 Regulation of biological process & 97 & 15 & 188 & 9 & 12 & 6 \\
\hline 发育过程 Developmental process & 24 & 4 & 100 & 4 & 5 & 3 \\
\hline 定位 Localization & 19 & 3 & 98 & 4 & 6 & 3 \\
\hline 定位建成 Establishment of localization & 15 & 2 & 91 & 4 & 5 & 3 \\
\hline 多细胞生物过程 Multicellular organismal process & 22 & 3 & 85 & 4 & 3 & 2 \\
\hline 多生物过程 Multi-organism process & 23 & 3 & 71 & 3 & 12 & 6 \\
\hline 繁殖 Reproduction & 12 & 2 & 57 & 3 & 5 & 3 \\
\hline 繁殖过程 Reproductive process & 11 & 2 & 55 & 2 & 4 & 2 \\
\hline 免疫系统过程 Immune system process & 8 & 1 & 27 & 1 & 6 & 3 \\
\hline 生长 Growth & 0 & 0 & 18 & 1 & 0 & 0 \\
\hline 死亡 Death & 0 & 0 & 16 & 1 & 3 & 2 \\
\hline 解剖结构形成 Anatomical structure formation & 10 & 1 & 15 & 1 & 3 & 2 \\
\hline 细胞组分 Cellular component & 474 & 100 & 1334 & 100 & 127 & 100 \\
\hline 细胞 Cell & 221 & 47 & 755 & 57 & 73 & 58 \\
\hline 细胞器 Organelle & 221 & 47 & 429 & 32 & 28 & 22 \\
\hline 大分子复合体 Macromolecular complex & 16 & 3 & 53 & 4 & 13 & 10 \\
\hline 包膜 Envelope & 7 & 1 & 43 & 3 & 5 & 4 \\
\hline 胞外区 Extracellular region & 8 & 2 & 41 & 3 & 8 & 6 \\
\hline 括膜腔 Membrane-enclosed lumen & 1 & 0 & 13 & 1 & 0 & 0 \\
\hline
\end{tabular}

蛋白(putative uncharacterized protein)。而下调 10 倍 以上的基因仅有 1 个，是含有胰蛋白酶抑制剂结构域 的蛋白(trypsin inhibitor domain containing protein)。

2.5 差异表达基因的实时苂光定量 PCR 验证

为了验证芯片数据的可靠性, 挑选 8 个差异表达 程度不同的基因(表 5)，进行实时苂光定量 PCR 的检
测。检测结果表明(图 3), 中双 11 的处理与对照比较, 尽管 8 个候选基因的差异表达倍数和芯片分析结果 存在一定差异, 例如, $D 1$ 在基因芯片的结果中是显 著下调的, 但是经苂光定量检测下调不明显, 但是 其上调或下调的趋势却是一致的。

在 Parter 中(图 3), FAE1、DGAT2、ACCase、 
表 42 个品种共同差异表达基因的功能注释(仅部分)

Table 4 Function annotation of partial common differentially expressed genes in the two rapeseed varieties

\begin{tabular}{ll}
\hline & 下调基因 Down-regulated gene \\
\hline DNA 结合蛋白 Putative DNA-binding protein & $\beta$-葡萄糖苷酶 Beta-glucosidase \\
$\alpha / \beta$ 水解酶家族 Alpha/beta-hydrolases family protein & GDSL 脂肪酶 GDSL esterase/lipase \\
富含半胱氨酸受体 Cysteine-rich receptor-like protein kinase 28 & 嘌呤核甘二磷酸解离抑制因子 RAB GDP-dissociation inhibitor \\
Myb 家族转录因子 Myb family transcription factor & 衰老相关蛋白 Senescence-associated protein \\
丝裂原活化蛋白激酶 Mitogen-activated protein kinases & 丝裂原活化蛋白激酶 Map 4 kinase alpha1 \\
磷酸激酶 Phosphoinositide-3-kinase & 肽基脯氨酰顺反异构酶 \\
磷酸甘油酸激酶 2-phosphoglycerate kinase & Peptidyl-prolyl cis-trans isomerase CYP19-3 \\
含 $\alpha / \beta$ 水解酶结构域的蛋白 & 识别起点的蛋白复合体 Origin recognition complex protein 5 \\
Alpha/beta-hydrolase domain-containing protein & 呵哚乙酸氨基化合成酶 \\
转运抑制剂应答因子 Transport inhibitor response & Indole-3-acetic acid-amido synthetase GH3.17 \\
WRKY DNA 结合蛋白 WRKY DNA-binding protein & 晚期胚胎富集蛋白 Dehydrin LEA \\
& 葡萄糖-6-磷酸转运体 \\
\hline \hline
\end{tabular}

上调基因 Up-regulated gene

\begin{tabular}{|c|c|}
\hline 酯酶 Esterase/lipase & 蛋白激酶家族蛋白 Protein kinase family protein \\
\hline 有机阳离子/肉毒碱转运体 Organic cation/carnitine transporter 2 & 病程相关蛋白 Pathogenesis-related protein \\
\hline 钙依赖性蛋白激酶 Calcium-dependent protein kinase & 锌指蛋白家族 Zinc finger $\left(\mathrm{C}_{2} \mathrm{H}_{2}\right.$ type $)$ family protein \\
\hline 果胶酯酶 Pectinesterase 6 & $\beta$-葡糖苷酶 Beta glucosidase \\
\hline 6-磷酸果糖激酶 6-phosphofructokinase & 渗透相似蛋白 Osmotin-like protein OSM34 \\
\hline 乙烯应答转录因子 Ethylene-responsive transcription factor & 含 LOB 结构域的蛋白 LOB domain-containing protein \\
\hline 海藻糖-6-磷酸合成酶 Putative alpha, alpha-trehalose-phosphate synthase & 类甲基转移酶蛋白 Methyltransferase-like protein \\
\hline COBRA 类似蛋白 COBRA-like protein & $\begin{array}{l}\text { 线粒体基质载体蛋白家族 } \\
\text { Mitochondrial substrate carrier family protein }\end{array}$ \\
\hline D-阿拉伯糖-1,4-内酯氧化酶 & 抗病蛋白 Disease resistance protein RPM1 \\
\hline $\begin{array}{l}\text { D-arabinono-1,4-lactone oxidase-like protein } \\
\text { 假定蛋白 Hypothetical protein }\end{array}$ & $\beta$-1,3-葡聚糖酶 Beta-1,3-glucanase \\
\hline 过氧化物酶 Peroxidase & $\begin{array}{l}\text { 乙烯应答元件结合因子 } \\
\text { Ethylene-responsive transcription factor ERF012 }\end{array}$ \\
\hline GDSL 脂肪酶 GDSL esterase/lipase & GDSL 脂肪酶 GDSL esterase/lipase \\
\hline 锌指蛋白 Zinc finger protein CONSTANS-LIKE & $\begin{array}{l}\text { 重构关键酶木葡聚糖内转糖苷酶/水解酶 } \\
\text { Xyloglucan endotransglucosylase/hydrolase protein }\end{array}$ \\
\hline 糖基水解酶家族 Glycosyl hydrolase family 17 protein & 可变剪接调控蛋白 Polypyrimidine tract-binding protein \\
\hline TRAF-like 家族蛋白 TRAF-like family protein & $\begin{array}{l}\text { 富含亮氨酸重复序列的蛋白 } \\
\text { Leucine-rich repeat-containing protein }\end{array}$ \\
\hline$\beta$-酮酯酰-CoA 合酶 $\beta$-Ketoacyl-CoA synthase & $\begin{array}{l}\text { 水溶性叶绿素结合蛋白 } \\
\text { Water-soluble chlorophyll-binding protein }\end{array}$ \\
\hline
\end{tabular}

FAD2、PEPC、Up1 和 $U p$ 在 2 种检测手段中的表达 变化趋势是一致的, 但是 $D 1$ 在芯片的分析结果中 是下调的, 但苂光定量 PCR 的检测却是上调的。综 合 8 个基因在 2 个品种中的检测结果, 2 种检测手段 的吻合率达 $94 \%$, 说明绝大部分芯片数据具有生物 学意义上的可重复性, 结果是可信的。

\section{3 讨论}

本研究采用基因芯片技术构建了 2 个油菜品种 在施氮和未施氮处理下基因表达谱数据库。为了验 证数据的准确性和可靠性, 运用实时苂光定量方法
验证差异表达基因, 发现 2 种检测手段的吻合率达 $94 \%$ ，表明本研究及其数据的可靠性和准确性; 但 是基因 $D 1$ 的检测结果出现偏差这可能源自不同生 物学实验手段本身的局限性, 或不同实验室所掌握 的技术水平参差不齐 ${ }^{[20-21]}$ 。

不同氮肥条件下, 2 份油菜品种种子含油量与蛋 白质含量的测定结果显示, 品种间确实存在对氮素 的敏感性差异, 中国高含油量品种中双 11 对氮素的 敏感性较德国品种 Parter 低, 表明今后有可能从多 样性丰富的油菜品种资源中篮选出对氮素的敏感性 更低的优异种质。 
表 5 挑选的 8 个基因在基因芯片中的差异表达 Table 5 Differential expression of eight selected genes assessed by microarray

\begin{tabular}{lccc}
\hline $\begin{array}{c}\text { 基因名称 } \\
\text { Gene name }\end{array}$ & $\begin{array}{c}\text { 探针编号 } \\
\text { Probe set ID }\end{array}$ & $\begin{array}{c}\text { 中双 11 C/A } \\
\text { Zhongshuang } \\
11 \text { C/A }\end{array}$ & $\begin{array}{c}\text { Parter } \\
\text { C/A }\end{array}$ \\
\hline ACCase & A_46_P009521 & 1.12 & -1.40 \\
PEPC & A_46_P183394 & 1.03 & 2.01 \\
DGAT2 & A_46_P374545 & -1.19 & -1.34 \\
FAE1 & A_46_P008926 & -1.04 & -6.91 \\
FAD2 & A_46_P008841 & 1.11 & -1.22 \\
Up1 & A_46_P192524 & 3.19 & 178.25 \\
Up2 & A_46_P036011 & 154.14 & 4.32 \\
$D 1$ & A_46_P199019 & -27.56 & -5.83 \\
\hline
\end{tabular}

表达变化倍数为负值时表示下调表达。 $\mathrm{A}$ : 对照 $\left(0 \mathrm{~kg} \mathrm{hm}^{-2}\right.$ 氮 肥); C: 处理(180 kg hm${ }^{-2}$ 氮肥); C/A：处理相对对照的基因表达量。

Ratios with a negative sign indicate down-regulated expression. A: control $\left(0 \mathrm{~kg} \mathrm{hm}^{-2}\right.$ nitrogen application); C: treatment (180 $\mathrm{kg} \mathrm{hm}^{-2}$ nitrogen application); C/A: the relative gene expressions in treatment compared to control.

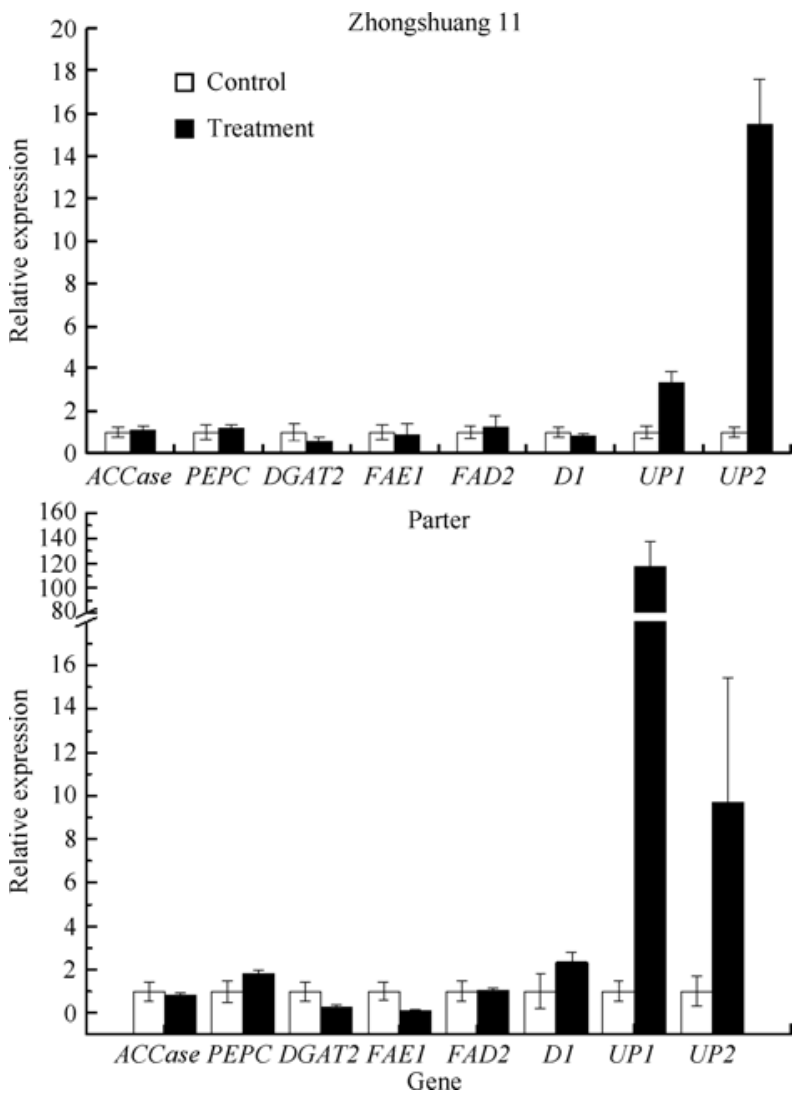

图 3 差异表达基因的实时荧光定量 PCR 验证 Fig. 3 Differentially expressed genes validated by real-time PCR

从全基因组表达水平看, 本研究得到的一个极 有趣结果, 即存在氮素敏感性差异的中双 11 和 Parter 在基因表达谱上存在极为显著的差异, Parter 中的差异表达基因数量是中双 11 的 4 倍, 并且
Parter 中差异表达大于 20 倍的基因比例(3.7\%)远远 大于高油品种中双 11 中的比例(1.4\%), 其上调和下 调基因的显著性均远远大于中双 11 。这种差异是否 是导致施氮后含油量和蛋白质含量变异程度不同的 原因, 有待进一步研究。今后应进一步研究确定这 些差异基因所属的代谢途径或基因网络。

通过分析 2 个品种有 278 个共同的差异基因，还 发现一些有潜在研究价值的重要基因, 例如水溶性 叶绿素结合蛋白 (water-soluble chlorophyll-binding protein, WSCP)基因, 该基因在中双 11 中的表达水 平上调了约 15 倍, 在 Parter 中表达水平约上调了 10 倍，此基因与植物蛋白合成和光合能力等代谢相关 ${ }^{[22]}$, 推测该基因的上调表达可能促进了 2 个品种中蛋白 的合成。我们还发现了类似 S-腺苷-L-甲硫氨酸依赖 的甲 基转移酶蛋白 (S-adenosyl-L-methionine-dependent methyltransferase-like protein), 在中双 11 中的 表达水平提高了约 50 倍, 而在 Parter 中仅提高 2 倍, 该酶参与 S-腺苷甲硫氨酸的转甲基作用, 40 多种代 谢反应与 S-腺苷-L-甲硫氨酸转甲基作用有关，如核 酸、蛋白质和脂质。DNA 甲基化(DNA methylation) 是一种主要的表观遗传修饰形式, 在高等植物中普 遍存在，它在基因组防御、调控基因表达等方面有 重要作用 ${ }^{[23]}$, 该基因的差异表达暗示施氮后可能存 在一系列基因的甲基化表观调控。另外，转运抑制 应答因子(transport inhibitor response 1, TIR1)在 2 个 品种中的表达水平均下调。有研究表明 TIR1 是生长 素受体之一 ${ }^{[24-25]}$, 调控植物发育和防卫反应 ${ }^{[26]}$, 抑 制该基因的表达，从而抑制生长素的反应，并影响 与植物生长素相关的一系列生命活动。氮素作为信 号分子使得信号传导分子的表达发生了变化, 进一 步说明氮素对油菜籽蛋白和油脂含量的影响是多个 代谢与调控过程综合作用的结果，这些基因共同作 用可能造成 2 个品种处理中蛋白质含量提高而含油 量下降。

\section{4 结论}

随施氮量的增加中双 11 和 Parter 的含油量均降 低, 而蛋白质含量提高。中双 11 和 Parter 分别有 827 个和 3676 个差异表达基因, 明显存在基因型的差异; 2 个品种共同的差异基因有 278 个, 其中上调表达的 151 个, 下调表达的 80 个。其功能主要是具催化活性、 结合和转录调节活性等分子功能, 参与细胞、代谢、 应激和生物调节等生物过程, 还发现大量未知功能 
的差异基因。基因芯片是发现功能基因的可靠、有 效手段。

\section{References}

[1] USDA. Foreign Agricultural Service Oilseeds: World Markets and Trade Monthly Circular. [2010-05-11] http://www.fas.usda. gov/oilseeds/circular/ Current.asp

[2] Liu H-L(刘后利). Practical Cultivation of Rapeseed (实用油菜 栽培学). Shanghai: Shanghai Scientific and Technical Publishers, 1987 (in Chinese)

[3] Li Z-Y(李志玉), Guo Q-Y(郭庆元), Liao X(廖星), Qin Y-P(秦亚 平). Effects of different amount of nitrogen on yield, quality and economics of Zhongshuang No.9. Chin J Oil Crop Sci (中国油料 作物学报), 2007, 29(2): 78-82 (in Chinese with English abstract)

[4] Liu C-Z(刘昌智), Cai C-B(蔡常被), Chen Z-X(陈仲西), Tu Y-C(涂运昌), Li Z-Y(李致云). Effects of nitrogen, phosphorus and potassium on yield protein and oil content of oilseed. Oil Crop China (中国油料), 1982, (3): 25-29 (in Chinese)

[5] Zhao H-J(赵合句), Li P-W(李培武), Li G-M(李光明), Lu S-G(陆师国). Effects of fertilizer dressing on biochemical qualities in quality rape (Brassica napus). Acta Agron Sin (作物 学报), 1991, 7(4): 255-259 (in Chinese with English abstract)

[6] Zhou N-N(周年年). The Research on the Nitorgen's Effect on Rapeseed Yield and Quality and Relevant Analysis. MS Dissertation of Huazhong Agricultural University, 2005 (in Chinese with English abstract)

[7] Zhao J-X(赵继献), Cheng G-P(程国平), Ren T-B(任廷波), Gao Z-H(高志宏). Effect of different nitrogen rates on yield and quality parameters of high grade yellow seed hybrid rape. Plant Nutr Fert Sci (植物营养与肥料学报), 2007, 13(5): 882-889 (in Chinese with English abstract)

[8] Wilcox J R. Increasing seed protein in soybean with eight cycles of recurrent selection. Crop Sci, 1998, 38: 1536-40

[9] Chung J, Babka H L, Graef G L, Staswick P E, Lee D J, Cregan P B, Shoemaker R C, Specht J E. The seed protein, oil and yield QTL on soybean linkage group I. Crop Sci, 2003, 43: 1053-1067

[10] Beisson F, Koo A J, Ruuska S, Schwender J, Pollard M, Thelen J J, Paddock T, Salas J J, Savage L, Milcamps A, Mhaske V B, Cho Y, Ohlrogge J B. Arabidopsis genes involved in acyl lipid metabolism. A 2003 census of the candidates, a study of the distribution of expressed sequence tags in organs, and a webbased database. Plant Physiol, 2003, 132: 681-697

[11] Nanjo T, Fujita M, Seki M, Kato T, Tabata S, Shinozaki K. Toxicity of free proline revealed in a Arabidopsis T-DNA-Tagged mutant deficient in proline dehydrogenase. Plant Cell Physiol, 2003, 44: 541-548

[12] Lorkowski S, Cullen P M. Analysing Gene Expression: a Handbook of Methods Possibilities and Pitfalls. New York: John Wiley and Sons, Inc. 2003

[13] Schena M, Shalon D, Davis R W, Brown P O. Quantitative monitoring of gene expression patterns with a complementary DNA microarray. Science, 1995, 270: 467-470

[14] Scheible W R, Fry B, Kochevenko A, Schindelasch D, Zimmerli L, Somerville S, Loria R, Somerville C R. An Arabidopsis mutant resistant to thaxtomin A, a cellulose synthesis inhibitor from Streptomyces species. Plant Cell, 2003, 15: 1781-1794

[15] Fu S-X(付三雄), Qi C-K(戚存扣). Identification of genes differentially expressed in seeds of Brassica napus planted in Nanjing and Lhasa by Arabidopsis microarray. Chin Bull Bot (植物学报), 2009, 44(2): 178-184 (in Chinese with English abstract)

[16] Trick M, Cheung F, Drou N, Fraser F, Lobenhofer E K, Hurban P, Magusin A, Town C D, Bancroft I. A newly-developed community microarray resource for transcriptome profiling in Brassica species enables the confirmation of Brassica-specific expressed sequences. BMC Plant Biol, 2009, 9: 50-59

[17] Hu Y, Wu G, Cao Y, Wu Y, Xiao L, Li X, Lu C. Breeding response of transcript profiling in developing seeds of Brassica napus. BMC Mol Biol, 2009, 10: 49-65

[18] Vicient C M, Delseny M. Isolation of total RNA from Arabidopsis thaliana seeds. Anal Biochem, 1999, 268: 412-413

[19] Livak K J, Schmittgen T D. Analysis of relative gene expression data using real-time quantitative PCR and the $2^{-\Delta \Delta C t}$ method. Methods, 2001, 25: 402-408

[20] Udall J A, Flagel L E, Cheung F, Woodward A W, Hovav R, Rapp R A, Swanson J M, Lee J J, Gingle A R, Nettleton D, Town C D, Chen Z J, Wendel J F. Spotted cotton oligonucleotide microarrays for gene expression analysis. BMC Genomics, 2007, 8: 14712164

[21] Li L-Y(李龙云), Yu W-W(于雾雯), Zhai H-H(翟红红), Huang S-L(黄双领), Li X-L(李兴丽), Zhang H-W(张红卫), Zhang J-F (张金发), Yu S-X(喻树迅). Identification of fiber length-related genes using cotton oligonucleotide microarrays. Acta Agron Sin (作物学报), 2011, 37(1): 95-104 (in Chinese with English abstract)

[22] Desclos M, Dubousset L, Etienne P, Caherec F L, Satoh H, Bonnefoy J, Ourry A, Avice J C. A Proteomic Profiling approach to reveal a novel role of Brassica napus drought $22 \mathrm{kD} /$ WaterSoluble chlorophyll-binding protein in young Leaves during nitrogen remobilization induced by stressful conditions. Plant Physiol, 2008, 147: 1830-1844

[23] Cheng X, Blumenthal R M. S-Adenosylmethionine-Dependent Methyltransferases: Structures and Functions, Singapore: World Scientific, 1999. pp 5-8

[24] Spartz A K, Gray W M. Plant hormone receptors: new perceptions. Gene Dev, 2008, 22: 2139-2148

[25] Kepinski S, Leyser O. The Arabidopsis F-box protein TIR1 is an auxin receptor. Nature, 2005, 435: 446-451

[26] Wang D, Pajerowska-Mukhtar K, Culler A H, Dong X. Salicylic acid inhibits pathogen growth in plants through repression of the auxin signaling pathway. Curr Biol, 2007, 17:1784-1790 